\title{
AGAMA MUSUH PANCASILA? STUDI SEJARAH DAN PERAN AGAMA DALAM LAHIRNYA PANCASILA
}

\author{
RELIGION OF PANCASILA'S ENEMY? \\ HISTORY STUDY AND THE ROLE OF RELIGION IN PANCASILA'S BIRTH
}

\author{
Aqil Teguh Fathani \\ Student Master of Government Affairs and Administration \\ Jusuf Kalla School of Government, \\ Universitas Muhammadiyah Yogyakarta \\ aqil.teguh.psc19@mail.umy.ac.id \\ Zuly Qodir \\ Master of Government Affairs and Administration, \\ Jusuf Kalla School of Government, Universitas Muhammadiyah Yogyakarta \\ zuliqodir@umy.ac.id
}

Naskah diterima tanggal 9 Maret 2020, Naskah direvisi tanggal 30 April 2020, Naskah disetujui tanggal 9 Juni 2020

\begin{abstract}
Abstrak
Tulisan ini membahas mengenai hubungan, sejarah dan peran agama dalam lahirnya Pancasila sebagai ideologi bangsa Indonesia. Agama dan Negara tidak bisa dibenturkan dalam konteks apa pun, agama dan negara memiliki hubungan yang mutualisme atau saling menguntungkan. Agama membutuhkan negara dalam merealisasikan nilai-nilai agama dalam kehidupan dan negara membutuhkan agama dalam menjalankan pemerintahan yang adil, bersih dan menyejahterakan rakyat serta dalam mengelola negara sekalipun. Selanjutnya dalam perumusan ideologi bangsa, agama memiliki peran yang besar dalam lahirnya Pancasila, kelapangan hati beberapa tokoh Islam dalam pembentukan Pancasila serta menghapus tujuh kata dalam Piagam Jakarta merupakan bentuk kedewasaan sikap dalam menyatukan rakyat Indonesia yang berasal dari berbagai latar belakang. Tidak sepatutnya seorang, kelompok atau siapa pun itu yang mengatakan bahwa agama adalah musuh Pancasila. Agama telah dijamin dalam Undang-Undang 1945 dan dalam sila pertama. Sebaliknya dengan adanya agama hidup berbangsa dan bernegara dapat berjalan dengan harmonis.
\end{abstract}

Kata Kunci: agama, ideologi, Pancasila, negara

\begin{abstract}
This paper discusses the relationship, history, and role of religion in the birth of Pancasila as the ideology of the Indonesian people. Religion and the State cannot clash in any context, religion and the state have a mutually beneficial or mutually beneficial relationship. Religion needs the state in realizing religious values in life and the state needs religion in carrying out a just, clean and prosperous government and even in managing the country. Furthermore, in the formulation of the ideology of the nation, religion has a major role in the birth of Pancasila, the hearts of some Islamic figures in the formation of Pancasila and the erasing of the seven words in the Jakarta Charter is a form of maturity of attitudes in uniting the Indonesian people from various backgrounds. It is not right for a person, group or anyone to say that religion is the enemy of Pancasila. Religion has been guaranteed in the 1945 Law and the first precepts. Conversely, with the existence of a state and state life religion can run harmoniously.
\end{abstract}

Keywords: religion, ideology, Pancasila, state

\section{PENDAHULUAN}

$\mathrm{K}$

eberadaan Pancasila sebagai falsafah kenegaraan berfungsi sebagai filosofische grondslag dan common platforms atau kalimatun sawa di antara masyarakat dalam konteks kehidupan berbangsa dan bernegara (Pramono, 2018). Pancasila sebagai ideologi bangsa berbeda 
dengan sistem yang dianut oleh kapitalisliberal dan sosial-komunis, Pancasila mengakui melindungi hak individu hingga hak masyarakat pada semua aspek kehidupan. Indonesia sendiri lahir karena disatukan dari berbagai jenis ras, bahasa, budaya dan agama yang berbeda serta wilayah yang berbentuk kepulauan (Asshiddiqie, 2006). Realitas ini menjadikan Indonesia sebagai bangsa yang plural berdimensi multikultural dan dapat menyat u menjadi sebuah bangsa (Widisuseno, 2015). Menurut (Muslimin, 2016) ideologi Pancasila dikenal sebagai ideoogi terbuka yang mampu mengikuti arus perkembangan zaman, dinamis, pemikiran yang terbuka dan merupakan hasil dari kesepakat an masyarakat. Dalam menjalankan sistem hukum dan ketatanegaraan di Indonesia, Ideologi Pancasila dijadikan sebagai rujukan karena memiliki peran penting atas nilai-nilai dasar kehidupan masyarakat (Sutrisno, 2016). Selain itu penerapan nilai Pancasila dalam kehidupan bermasyarakat dan bernegara merupakan suatu kewajiban agar Pancasila selalu relevan dalam memberikan pedoman serta menjadi jalan terbaik dalam pemecahan suatu masalah (Eddy, 2018).

Pancasila sebagai dasar negara dijadikan untuk tidak terlepas dari arus globalisasi, perkembangan ilmu pengetahuan dan teknologi. Perkembangan globalisasi juga memiliki dampak yang tidak bisa dihindarkan, pembudayaan nilai-nilai Pancasila perlu diupayakan pada seluruh aspek kehidupan masyarakat (Asmaroini, 2017). Demokrasi Pancasila timbul dari nilai-nilai masyarakat asli Indonesia yang melekat padanya, selain itu demokrasi Pancasila merupakan jalan tengah yang harus disikapi dengan bijak karena merupakan alternatif pemersatu bangsa (N. R. Yunus, 2016). Pancasila muncul pada saat kesadaran bersama pada saat masamasa krisis, kesadaran ini muncul dari keberanian unt uk berkorban demi kepentingan yang besar dalam membentuk bangsa yang besar (Said Ali, 2009). Pancasila memiliki hubungan yang erat dengan agama. Hubungan ini senantiasa menghadirkan sebuah konsekuensi hukum di Indonesia yang berlandaskan ketuhanan yang maha esa sehingga negara berhak mengurusi agama dan kepercayaan (Shaleh \& Wisnaeni, 2019).

$$
\text { Pancasila sejatinya tidak }
$$

bertentangan dengan apapun, Pancasila telah disepakati bersama oleh pendiri bangsa yang berasal dari berbagai latar belakang yang berbeda (Manggalatung, 2017). Akan tetapi pada belakangan ini Pancasila sering dibenturkan dengan berbagai persoalan salah sat unya agama. Pernyataan yang dikeluarkan ketua Badan Pembinaan Ideologi Pancasila (BPIP) mengenai "Agama Adalah Musuh Pancasila" dengan alasan kekerasan di republik ini selalu mengatasnamakan agama membuat publik heboh, walaupun adanya keterangan klarifikasi yang dikeluarkan oleh BPIP tidak menyurutkan publik untuk selalu bertanya-tanya mengenai pernyataan awal terebut. Pada tulisan ini peneliti akan mengkaji mengenai "Sejarah dan Peran Agama dalam Lahirnya Pancasila, Hubungan Agama dengan Negara dan Islam dan Negara" sehingga tidak ada lagi pergesekan secara subjek dan objek dalam penyelenggaraan agama dan negara.

\section{TINJAUAN PUSTAKA}

\section{Pancasila}

Ideologi Pancasila menjadi sumber dalam ketatanegaraan yang dijadikan dalam membangun negara Indonesia, Pancasila menjadi peran penting dalam sistem hukum dan konstitusi Indonesia (Sutrisno, 2016). Nilai-nilai Pancasila pada hakikatnya merupakan nilai yang terbentuk dari nilai luhur dan kebudayaan bangsa Indonesia yang bersumber dari nilai-nilai kebudayaan secara keseluruhan (Kaelan, 2007). Menurut Dauglas (1995) menyebutkan bahwa Pancasila merupakan jalan tengah dari keseluruhan kepentingan. Menurut (Widisuseno, 2015) Pancasila sebagai ideologi negara secara filosofis memiliki akar yang tumbuh dalam masyarakat Indonesia sebelum berdirinya bangsa dan negara Indonesia, secara epistemologi Pancasila terbukti memiliki nilai kebenaran yang testable, falsifiable, refutable sehingga bisa menyatukan keberagaman masyarakat bangsa Indonesia. 
Ideologi Pancasila dikenal sebagai ideologi terbuka yang mampu mengikuti arus perkembangan zaman, dinamis dan pemikiran terbuka sehingga penerapan Pancasila sebagai ideologi bangsa dapat terus berjalan (Muslimin, 2016). Pada hakikatnya fungsi Pancasila tidak berubah dalam artian tetap sebagaimana yang dirancang oleh pendiri bangsa sebagai pedoman, ideologi dan dasar bangsa. Akan tetapi Pancasila sebagai ideologi terbuka mampu menyesuaikan perkembangan zaman yang terus berubah (Ibrahim, 2010). Kebenaran nilai Pancasila bagi bangsa Indonesia sudah terbukti melalui berbagai kajian ilmiah. Bagi Indonesia Pancasila merupakan imperatif bukan alternatif, Pancasila berguna untuk mempersatukan keragaman yang dimiliki bangsa Indonesia dari suku, agama, ras, budaya dan golongan (Mulyono, 2016).

Indonesia sebagai negara yang menganut paham Bineka Tunggal Ika faktanya belum mampu untuk menunjukkan kekuatannya dalam menangkal pemahaman radikal dan ekstrem dari sebagian pemeluk agama, dangkalnya pemahaman tentang agama dan fanatik menimbulkan rasa superioritas terhadap agama lain (Laisa, 2014).

\section{Radikalisme Agama}

Dimensi politik global merupakan salah satu penyebab terjadinya radikalisme, setelah dilakukan penelusuran lebih dalam oleh para ahli menyimpulkan tragedi kemanusiaan di berbagai belahan dunia merupakan contohnya (Ritaudin, 2014). Maraknya perkembangan radikalisme di Indonesia harus mampu dikondisikan, pada kalangan muda terdidik banyak yang terjangkit paham radikal dan terus bertumbuh pesat (Rijal, 2017). Radikalisme agama pada saat ini sedang marak terjadi di Indonesia, munculnya berbagai alasan lahirnya tindakan kekerasan salah satunya dari aspek sosiologi. Terdapat tiga aspek sosiologi dalam gerakan sosial keagamaan yaitu, orientasi politik, orientasi agama dan orientasi kultural rakyat Indonesia (Qodir, 2014). Ada beberapa alasan yang menjadi faktor munculnya radikalisme di Indonesia yaitu, perkembangan di tingkat global, penyebaran paham Wahabi, dan kemiskinan (Asrori, 2017). Munculnya tindakan radikalisme pada kaum muslim disebabkan karena mereka hanya berpegang pada Al-Qur'an dan hadis yang dipahami secara literal, harfiah dan skriptural sehingga melahirkan pemahaman yang fanatik eksklusif dan hitam-putih (Mufid, 2016).

Fundamentalisme dan radikalisme merupakan kata yang tidak ada dalam bahasa kaum muslim di Timur Tengah (Ahda, 2017). Berbagai analisa mengungkapkan bahwa radikalisme agama tumbuh dari politik global dunia Islam yang secara berkelanjutan menjadi objek adu domba (A. F. Y unus, 2017). Di Indonesia kemunculan radikalisme muncul pasca orde baru yang berkaitan dengan politik demokrasi serta dampak kebijakan negara atas radikalisme (Hilmy, 2015). Penyebaran paham radikalisme dapat dibendung dari berbagai kebijakan negara yaitu, melalui kebijakan menanam bahaya radikalisme dalam pendidikan (Aziz, 2016). Pendidikan dalam jenjang sekolah dasar sangat berperan penting dalam menangkal pemahaman radikalisme di Indonesia, sekolah dasar dapat mengajarkan Islam yang konstektual dan Kaffah (Arifin \& Rizal, 2016). Selain itu yang paling penting dalam menanggulangi ancaman radikalisme yaitu perlu adanya penguatan pemahaman nilai-nilai Pancasila agar loyalitas masyarakat terhadap Pancasila tetap tinggi (Eddy, 2018).

Setelah era reformasi, Indonesia masih banyak terjadinya kerusuhan dan konflik sosial, semakin banyaknya konflik sosial menimbulkan pertanyaan apakah nilainilai Pancasila sebagai ideologi negara mampu menjawab persoalan kerusuhan di Indonesia (Fauzi, 2017). Ada beberapa tawaran solutif untuk meminimalisir tindakan radikalisme politik dunia yaitu, keniscayaan mengakui adanya perbedaan, menolak paham absolutisme dan pemikiran terorisme, radikalisme, fundamental dan demokrasi bersifat relatif, mengakui kesetaraan dalam konsep kehidupan (Ritaudin, 2014).

\section{METODE PENELITIAN}

Penulisan ini menggunakan metode kualitatif dengan menggunakan pendekatan metode sejarah yang terdiri dari beberapa langkah yaitu, pertama mengumpulkan materi yang berkaitan dengan lahirnya ideologi Pancasila serta jalan terbentuknya ideologi Pancasila. Pengumpulan materi dilakukan 
dengan mengakses jurnal serta buku-buku yang berkaitan dengan pembahasan penelitian. Materi yang didapatkan selanjutnya diseleksi dan dianalisis serta dirangkai dan disusun menjadi satu kesatuan yang saling berhubungan dan sesuai dengan pembahasan penelitian.

Tahap akhir dalam penulisan yaitu historiografi, berupa hasil analisis yang telah dilakukan disusun secara sistematis dan kronologis dalam tulisan yang bersifat deskriptif kualitatif.

\section{PEMBAHASAN}

\section{Sejarah Lahirnya Pancasila}

Perbedaan mengenai landasan negara yang akan diambil untuk dijadikan sebagai dasar negara telah terjadi sejak tahun 1938 hingga pada persiapan kemerdekaan republik Indonesia, perbedaan pendapat ini terjadi antara kelompok nasionalis Soekarno dengan kelompok Islam yang dipimpin oleh Muhammad Natsir yang menginginkan negara Islam sebagai landasan negara. Kelompok Nasionalis menginginkan Pancasila sebagai dasar negara sedangkan kelompok Islam menginginkan Islam sebagai dasar negara, perbedaan pandangan agama dan negara antara Soekarno dan Natsir dimulai dengan adanya artikel dari Soekarno dengan judul "Sebab Turki Memisahkan Agama dan Negara" pada tahun 1940. Soekarno memandang bahwa pemisahan agama dan negara karena agama adalah urusan spiritual sedangkan negara urusan dunia, hal ini telah dilakukan oleh negara Turki pada masa Kemal Attaturk serta juga merujuk dari pendapat ulama Al-Azhar Syeikh Ali Abdur Razid (Ahmad, 1999). Seokarno juga merujuk perkataan Mahmud Essay Bey yaitu apabila agama dipakai dalam mengelola negara, makan selalu digunakan sebagai alat untuk menghukum di tangan raja-raja, orang zalim dan tangan besi (Hamidi, Jazim, \& Abadi, 2001).

Dapat diartikan pemisahan ini bisa dikatakan bentuk sekularisasi yang dilakukan Soekarno karena tidak ingin menggabungkan urusan negara, politik, sosial, ilmu pengetahuan, teknologi dengan pengaruh agama atau hal-hal gaib. Sekuler merupakan kata yang menunjukkan suatu keadaan yang memisahkan antara kehidupan duniawi dari pengaruh spiritual, sehingga menimbulkan dikotomi antara kehidupan realitas dengan kehidupan sakral. Sebagai contoh negaranegara barat banyak mengimplementasikan kehidupan seperti ini (Kasmuri, 2014).

Kemudian pendapat Muhammad Natsir dari kalangan agama menyatakan bahwa agama dan negara tidak bisa dipisahkan karena urusan kenegaraan pada hakikatnya adalah bagian dari risalah Islam, dalam membangun negara perlunya inspirasi dari nilai-nilai Islam karena orang beragama atau Islam memiliki pedoman hidup, ideologi yang semuanya mencakup pada Al-Qur'an dan As-Sunnah. Beliau juga mengkritik pernyataan Soekarno mengenai agama dan negara yang menjadikan Turki pada masa Kemal Attaturk sebagai rujukan, Natsir menganggap pada masa Kemal Attaturk berkuasa bukanlah contoh yang pas dari negara Islam, dalam pandangan Islam negara bukanlah tujuan akhir, negara hanya sebagai media untuk merealisasikan ajaran-ajaran Islam yang ada pada Al-Qur'an dan Sunnah (Suhelmi, 1999).

Dalam perbedaan pendapat antara Soekarno dan Natsir dapat disimpulkan pandangan mengenai negara Islam yaitu pertama, konsep kehidupan negara adalah aktualisasi keberadaan manusia sebagai makhluk ciptaan Allah SWT yang pada hakikatnya taat kepada Allah serta dalam berhubungan sesama makhluk hidup harus berjalan sesuai yang ada dalam aturan nilainilai Islam. Kedua, negara adalah media unt uk membuat aturan yang sesuai dengan perintah Allah SWT. Melalui kekuasaan negara nilainilai Islam dapat diimplementasikan karena negara mempunyai kewenangan untuk membuat, menjalankan dan menegakkan at uran. Ketiga Islam merupakan agama yang dianut oleh sebagian besar masyarakat Indonesia oleh karenanya nilai Islam telah tumbuh dan berkembang dalam diri masyarakat Indonesia. Natsir mempertegas bahwa pola negara Islam anti terhadap rezim atau pemimpin yang otoriter, dalam pandangan Islam menjelaskan bahwa dalam 
melaksanakan

pemerintahan

harus

menjunjung tinggi musyawarah dan mengaktualisasikan nilai-nilai yang sudah terkandung dalam Al-Qur'an dan Hadist. Hal terebut merupakan benang merah tentang gagasan mengenai agama dan negara pada saat perdebatan antara Soekarno dan Natsir pada tahun 1940.

Muhammad Natsir juga membandingkan antara konsep Islam dengan sekuler dalam mengelola negara, beliau mengatakan agama memberikan hambanya kemungkinan untuk mempelajari ilmu pengetahuan dan kebenaran. Falsafah berpikir sekuler hanya mengakui tiga hal yaitu empirisme, rasionalisme dan intuisionisme. Sementara dasar wahyu dalam pemikiran sekuler tidak diakui. Agama lebih dari pada sekuler, agama mengakui segala hal dan memberikan ketentuan yang tegas sesuai dengan daerah berlakunya masing-masing, oleh karenanya agama meliputi jangkauan yang luas dalam aspek seluruh kehidupan manusia dibandingkan dengan pemikiran sekuler (Arianto, 2018)

Perdebatan panjang antara Soekarno dan Natsir ini semakin meluas hingga sampai pada saat proses pembentukan negara Indonesia pada tahun 1945. Dalam upaya untuk menyusun dasar negara dibentuklah Badan Penyelidik Usaha-Usaha Persiapan Kemerdekaan (BPUPKI) dan diresmikan pada 28 Mei 1945. Pembentukan BPUPKI ini terdiri dari 8 orang dari Jepang, 15 orang golongan Islam dan selebihnya adalah golongan nasionalis dan pribumi jawa, jika dilihat dari jumlah keseluruhan golongan Islam dalam anggota BPUPKI hanya berjumlah 20\% (Thaba, 1996). Perdebatan mengenai dasar negara antara kelompok Islam dan kelompok nasional dalam sidang BPUPKI terus terjadi, kelompok Islam menginginkan Islam sebagai dasar negara, sedangkan kelompok nasional menginginkan Pancasila sebagai dasar negara (Romli, 2006).

Tidak ketemunya titik terang landasan negara pada saat sidang BPUPKI, dibentuklah panitia kecil yang beranggota 9 orang yang dipimpin oleh Ir. Soekarno. Anggota ini terdiri dari Muhammad Hatta, Achmad Subardjo, Muhammad Yamin dan AA Maramis dari kelompok nasionalis dan $\mathrm{H}$. Agus Salim, Wahid Hasyim, Abikusno dan
Abdul Kahar Muzakkir dari kelompok Islam. pada 22 Juni 1945 terjadi kesepakatan antara kelompok nasionalis dan kelompok Islam untuk menambah tujuh kata pada sila pertma yaitu "Ketuhanan Dengan Kewajiban Menjalankan Syari'at Islam Bagi Pemelukpemeluknya". Setelah pembacaan proklamasi pada 17 Agustus 1945 sila pertama diubah menjadi "Ketuhanan Yang Maha Esa" dengan alasan untuk persatuan bangsa, meminimalisir ketegangan politik yang tinggi dan optimisme umat Islam dalam memenangkan pemilu 6 bulan setelah proklamasi. Perubahan kata dalam Pancasila ini dilakukan atas lobby Muhammad Hatta dengan mempertimbangkan tiga alasan tersebut (Thaba, 1996). Menurut pandangan Muhammad Yamin gagasan yang disampaikan oleh kelompok Islam untuk menjadikan Islam sebagai dasar negara tidak memiliki argumen yang kuat mengenai konsep negara Islam yang diinginkan, akan tetapi lebih kepada jaminan terhadap pelaksaan syari'at-syari' at Islam.

Dari penentuan ideologi dasar negara yang rumit hingga adanya perdebatan panjang. Melihat gagasan-gagasan yang diberikan Soekarno dan Natsir di atas menggambarkan adanya pertentangan gagasan yang tajam di antara dua tokoh tersebut. Soekarno berdasarkan analisis sejarah yang mengatakan negara dan agama tidak bisa disatukan dan harus dipisahkan. Muhammad Natsir berdasarkan analisis bahwa negara dan agama harus disatukan karena Islam merupakan agama yang mencakup seluruh aspek kehidupan termasuk dalam mengelola negara dan pemerintahan.

Perbedaan gagasan yang kuat antara dua tokoh bangsa ini dapat menjadi pelajaran dalam kehidupan sosial, dapat dilihat tidak adanya pergesekan dan benturan yang menimbulkan perpecahan dalam penentuan ideologi negara, walaupun kedua tokoh ini sama-sama menyampaikan argumen yang kuat. Kesimpulan akhir mengenai ideologi negara diputuskan dengan memilih Pancasila sebagai ideologi dasar negara, pada akhirnya golongan Islam menerima dengan sepenuh hati Pancasila sebagai ideologi negara. 


\section{Hubungan Agama dan Negara}

Pada dasarnya Undang-Undang Dasar 1945 tidak memisahkan hubungan antara agama dan negara, pernyataan ini bisa dilihat dalam sila pertama Pancasila dan Bab XI Undang-Undang Dasar 1945 tentang Agama. Hubungan agama dan negara sering kali menjadi pro dan kontra, dikarenakan agama sering kali digunakan untuk melakukan tindakan yang bertentangan dengan pemerintahan atau pemerintahan sering dijadikan kekuatan untuk menekan agama. Negara dalam pandangan Islam menurut (AlMawardi, 1950) yaitu di dalam negara ada agama yang dijunjung tinggi, di dalam negara ada penguasa yang berwibawa, di dalam negara harus ada keadilan, di dalam negara tercipta keamanan, di dalam negara ada generasi, dan di dalam negara harus terpenuhinya kebutuhan masyarakat. Berdasarkan pengertian tersebut salah satu unsur terpenting dalam suatu negara adalah agama.

Hubungan agama dengan negara dinilai sangat erat dan saling berhubungan dalam berbagai aspek. Berbagai kalangan cendekiawan, ilmuan dan agamawan di Indonesia menyepakati bahwa agama memberikan pedoman yang berasal dari tuhan dan berfungsi sebagai pembimbing dan pemberi petunjuk, dengan fungsi seperti ini tujuan pokok agama adalah keselamatan, kesejahteraan dan kedamaian kepada penganutnya (Ishak, 2014). Pemahaman terhadap pola hubungan agama dan negara dengan pendekatan Islam pada dasarnya tidak untuk mendirikan negara agama atau negara Islam, akan tetapi untuk mengisi ruang-ruang agama yang lebih fungsional dalam kehidupan berbangsa dan bernegara (Hasan, 2015).

Mengkaji tentang pola hubungan antara Agama dan Negara pada faktanya terjadi dalam sejarah yang panjang dan menjadi perbincangan yang serius sejak abad pertengahan hingga saat ini, dalam khazanah politik dan ketatanegaraan Islam atau Fiqh Siyasah ada tiga paradigma tent ang hubungan agama dan negara (Syamsudin, 2000). Pertama, antara agama dan negara merupakan satu kesatuan dan tidak dapat dipisahkan. Hubungan ini terikat khusus yaitu negara sebagai lembaga politik dan keagamaan sekaligus. Pemerintahan negara dijalankan dengan dasar "Kedaulatan Illahi" atau Devine Sovereignty dikarenakan kedaulatan berasal dari tangan tuhan. Beberapa tokoh Islam yang menganut paham ini yaitu Hasan Al-Banna, Sayyid Qutb dan Abu La'la Al-Maududi.

Kedua, agama dan negara memiliki hubungan timbal balik dan saling mempengaruhi atau Simbiotik-Interpenden yaitu agama memerlukan negara karena dengan melalui negara agama dapat menjadi berkembang. Sebaliknya negara memerlukan agama karena dengan agama negara dapat menjadi berkembang dalam kerangka etika dan moral. Para agamawan yang ada dalam golongan ini yaitu Mohammed Husein Haikal, Al-Mawardi, Fazlur Rahman dan Qamaruddin Khan. Ketiga hubungan agama dan negara yang bersifat sekularistik yaitu menolak hubungan timbal balik antara agama dan negara atau antara agama dengan negara terpisah dalam hubungan apa pun. Dari ketiga paradigma tersebut terdapat perbedaan dan cara pandang dalam memahami realitas antara agama dan negara sehingga mempengaruhi keberlangsungan jalannya sistem tata negara saat ini.

Selanjutnya Max Webber menyebutkan hubungan yang baik mengenai kekuasaan adalah berjalannya dengan stabil kehidupan sosial dalam hubungan agama dan negara serta ekonomi. Jika ditinjau dari konteks akademik hubungan agama dan negara tidak bisa lepas dari politik hukum di negara ini, menurut (Mahfud, 2017) hukum merupakan alat untuk mencapai cita-cita bangsa dan tujuan negara, dalam menjalankan rangkaian tersebut senantiasa untuk memperhatikan politik hukum dan reaksi dari hukum tersebut sehingga hubungan agama dan negara menjadi lebih harmonis dan bisa berdampingan dalam mencapai tujuan negara

Sejak masa reformasi, kehidupan demokrasi kembali dibangun dengan keluarnya Tap MPR RI No.X/MPR/1998 tentang Pokok-Pokok Reformasi, Tap MPR Ri No. XI/MPR/1998 tentang Penyelenggaraan Negara yang bebas dari KKN dan Amandemen UUD 1945 (I,II,III,IV) (Supriadi, 2017). Penetapan "Negara atas dasar Ketuhanan 
Yang Maha Esa” pada sila pertama memiliki makna yaitu pertama, Pancasila lahir dalam suasana yang sadar, batin dan kekuatan untuk melawan penjajahan kolonialisme dan imperialisme. Dalam melawan penjajahan diperlukan kesatuan dan persatuan di antara komponen bangsa, dengan lahirnya "Ketuhanan Yang Maha Esa" menjadi faktor penting untuk memperkuat persatuan dan kesatuan. Kerelaan hati beberapa tokoh Islam yang menjadi founding fathers untuk menghapus kalimat "Dengan Kewajiban Menjalankan Syariat Islam bagi pemelukpemeluknya" mencerminkan bahwa Pancasila mampu menjaga dan memelihara persatuan di antara keberagaman komponen bangsa.

Kedua, pada seminar Pancasila pada tahun 1959 di Yogyakarta menyimpulkan bahwa nilai "Ketuhanan Yang Maha Esa" harus menjadi pedoman dalam menjalankan poin negara dari rakyat, negara untuk rakyat dan negara oleh rakyat. Ketiga nilai "Ketuhanan Yang Maha Esa" merupakan satu kesatuan dengan sila-sila lainnya dalam Pancasila secara utuh. Pernyataan ini di pertegas dalam simpulan nomor 8 dari seminar yang dilakukan pada tahun 1959 di Yogyakarta. Keempat "Negara atas Ketuhanan Yang Maha esa" harus dimaknai bahwa negara dengan tegas melarang ajaran at au paham yang secara terbuka menolak nilai "Ketuhanan Yang Maha Esa" seperti Komunisme dan Atheisme. Hal ini dipertegas dengan ketetapan MPRS No. XXV tahun 1965 tentang larangan kegiatan untuk menyebarkan paham dan ajaran Komunisme, Marxisme, Leninisme. Dalam pasal 29 ayat 2 Undang-Undang Dasar bahwa "Negara menjamin kemerdekaan tiap-tiap penduduk untuk memeluk agamanya masingmasing......" hal ini dimaksudkan untuk bahwa negara hanya menjamin kemerdekaan untuk orang atau individu yang beragama. Dengan arti lain bahwa Pancasila tidak menjamin kebebasan untuk individu yang tidak memiliki agama (atheis).

Ketegangan hubungan antara agama dan negara pada saat ini terjadi karena tidak adanya hubungan timbal balik dan chekcs and balances. Dalam hubungan seperti ini dicontohkan seperti negara tidak memberikan kebebasan dan kemerdekaan bagi warganya untuk melaksanakan ibadah sesuai ajarannya masing-masing. Atau sebaliknya bahwa agama menganggap negara menutup diri terhadap nilai-nilai keagamaan sehingga jalannya negara bertentangan dengan nilainilai keagamaan. Sehingga muncul istilah bahwasanya "Agama adalah musuh Pancasila". Pada dasarnya istilah dinilai sangat keliru karena sangat bertentangan dengan sila pertama dalam Pancasila "Ketuhanan Yang Maha Esa". Kekeliruan ini menimbulkan kehebohan dalam masyarakat sehingga menimbulkan banyak statement yang beranggapan bahwa ketua BPIP Yudian Wahyudi tersebut seorang yang anti-agama sehingga menyampaikan pernyataan tersebut. Banyaknya ketegangan antara agama dan negara dari dahulu hingga sekarang menjadi polemik yang sulit dihentikan, pergesekan tersebut timbul karena negara tidak mampu menyeimbangkan tata negara dengan nilainilai agama (James \& Lutz J, 2004).

Indonesia telah memberikan jalan tengah dalam pembentukan dasar negara sehingga tidak perlu munculnya konflik agama atau konflik yang mengatasnamakan agama yang dapat mengganggu keutuhan nasional. Walaupun sempat beberapa kali timbulnya pemahaman sekuler dari elite politik dan elite pemerintahan yang berusaha untuk memisahkan agama dan negara sangat mengganggu kehidupan masyarakat. Hubungan antara negara dan agama sejatinya menghadirkan sebuah tatanan yang berlandaskan ketuhanan yang maha esa yang menegaskan bahwa negara atas nama konstitusi mengurusi agama dan kepercayaan sehingga munculnya pluralisme hukum dalam menjalani kehidupan politik, hukum dan sosial yang harmonis.

\section{Islam dan Negara}

Islam merupakan agama untuk kepentingan kehidupan dunia dan akhirat. Islam berisi tentang akidah, akhlak, ibadah serta berisi prinsip-prinsip hukum dan politik. Islam menuntun manusia mewujudkan kedamaian pada umat Islam khususnya dan seluruh manusia pada umumnya. Dalam sejarah peradaban Islam, Nabi Muhammad SAW sebagai pemimpin umat muslim dan pemimpin negara yang diakui oleh semu golongan barat maupun timur. Nabi Muhammad mendirikan negara dengan 
konstitusi negara bernama Piagam Madinah at au Konstitusi Madinah. Konstitusi Madinah merupakan kontrak sosial dalam bentuk hukum tertulis dari berbagai agama dan etnis yang berisi dasar-dasar kebebasan beragama, hubungan antar kelompok, agama, dan kewajiban mempertahankan hidup. Beberapa ahli didunia menyepakati bahwa konstitusi Madinah merupakan dokumen tertulis pertama didunia yang meletakkan dasar-dasar tata negara yang sangat fundamental (Shaleh \& Wisnaeni, 2019).

Sebagai sebuah landasan, negara Islam mengandalkan keberagaman pandangan karena negara Islam lahir dari respons terhadap perkembangan politik muslim yang sering menghadapi perubahan setelah runtuhnya kekhalifahan Turki Utsmani. Hingga saat ini persoalan negara Islam masih menjadi perdebatan di berbagai kalangan, bahkan sebagian negara yang mengklaim diri sebagai Islam malah memantik kritik dari kalangan Muslim sendiri seperti Abdul Raziq (Sahidah, 2011). Di Indonesia hubungan agama dan negara pada dasarnya dimaksudkan untuk mengisi ruang agama untuk menciptakan kehidupan yang bermasyarakat dalam berbangsa dan bernegara. Hubungan Islam dan negara harus diartikan untuk menghadapi perkembangan zaman dan perkembangan masyarakat dalam berbagai aspek lainnya seperti ekonomi, politik, globalisasi, sains, teknologi, isu-isu demokrasi, HAM, gender, pluralisme baik secara nasional ataupun internasional (Hasan, 2015)

Polemik keputusan terbentuknya negara Indonesia yang berlandaskan negara Pancasila dan negara Islam terjadi sebelum dan pasca kemerdekaan, Muhammad Natsir sebagai salah satu pendiri bangsa berpandangan bahwa ajaran Islam telah mengatur semua aspek kehidupan didunia ataupun di akhirat. Natsir memegang teguh prinsip bahwasanya orang yang beriman harus mengat ur keseluruhan hidupnya secara ajaran Islam (Ahmad, 1999). Natsir menjelaskan bahwa Islam sebagai ideologi merupakan suatu keharusan karena beliau seorang muslim yang taat dan meyakini kesempurnaan Islam didunia ataupun di akhirat. Selain itu juga mempertimbangkan aspek sosiologis yaitu karena sebagian besar masyarakat Indonesia merupakan penganut agama Islam dan dengan sendirinya nilai-nilai Islam tumbuh dan berkembang dengan subur dalam kehidupan bermasyarakat di Indonesia. Dari aspek muamalah Islam mengatur mengenai pola hidup individu, kekeluargaan dan hidup bernegara (Natsir, 1957). Oleh karena itu akan sangat membantu negara dalam menjalankan fungsi dan tujuan bernegara.

Beliau juga meluruskan pendapat banyak orang yang mengucilkan Islam dalam pengelolaan negara. Menurut Natsir pandangan negatif yang dibangun oleh kelompok orientalis mengenai konsep negara Islam sangat menakutkan, Islam selalu diidentikkan dengan hukuman mati, hukum rajam, potong tangan, cambuk dan poligami sehingga menimbulkan pandangan terhadap negara Islam bahwa merupakan suatu yang menakutkan untuk digunakan dalam mengelola negara. Natsir menilai ada mekanisme dalam penentuan kasus bagi seseorang yang melakukan kesalahan dalam ajaran Islam, kelompok orientalis dengan sengaja tidak mengungkit ajaran Islam yang solider, cinda damai, berkeadilan dan egaliter (Ahmad, 1999). Bahwa adanya kekeliruan pandangan kelompok orientalis dan sebagian kelompok nasionalis di Indonesia dalam memahami tentang agama Islam, kekeliruan ini membuat kelompok nasional ragu dan takut dengan pilihan Natsir dan golongan Islam tentang konsep negara Islam yang ditawarkan untuk menjadi dasar negara.

Orientalis merupakan kajian yang dilakukan oleh para ilmuan barat untuk mengkaji dan mempelajari dunia timur yang mencakup keseluruhan aspek yang meliputi agama, ilmu, ekonomi dan politik (Teng, 2016). Para peneliti Islam menyebutkan bahwa kelompok orientalis merupakan golongan non-muslim dari non-Arab yang mengkaji akidah, syari'at, bahasa dan peradaban Islam dengan tujuan untuk membuat keraguan pada agama sehingga manusia dapat jauh dari agama.

Indonesia yang merupakan negara yang memiliki landasan Pancasila tidak dapat mengklaim diri sebagai Negara Islam karena 
adanya keberagaman serta atas kesadaran dan kesepakatan bersama di antara Founding Fathers yang telah menyetujui dengan Pancasila sebagai dasar ideologi bangsa dan Undang-Undang Dasar 1945 sebagai konstitusi dalam menjalankan tatanan kenegaraan di Republik Indonesia. Melihat pemikiran dari pendiri bangsa tentang dasar negara Indonesia dipahami bahwa pilihan terhadap Pancasila merupakan hasil ijtihad atau kesepakatan bersama yang harus dijunjung tinggi agar terciptanya kehidupan yang sejahtera dan penuh dengan kedamaian.

\section{Diskusi}

Sejak awal sebelum terbentuknya bangsa Indonesia, para tokoh bangsa selalu disibukkan bagaimana cara untuk menyatukan masyarakat Indonesia yang sangat beragam dari suku, ras, agama dan golongan. Hingga terjadinya adu argumen antar tokoh pendiri bangsa guna mencari jalan terbaik yang digunakan untuk menjadi landasan dan pedoman untuk menyatukan masyarakat Indonesia. Pancasila telah ditetapkan sebagai dasar negara dan pandangan hidup yang merupakan hasil pemikiran beberapa tokoh besar perjuangan serta bentuk kelapangan hati tokoh muslim dalam menerima Pancasila sebagai ideologi negara.

Pancasila juga merupakan sumber hukum dan tatanan kehidupan bangsa yang selalu ditanamkan kepada seluruh masyarakat agar dapat dijalankan dan sesuai dengan yang dicita-citakan pendiri bangsa. Pancasila yang menggandeng konsep ideologi terbuka serta memiliki nilai dasar, nilai instrumental dan nilai praktis yang harus mampu mengikuti perkembangan zaman (Pramono, 2018). Nilai dasar yang dimaksudkan yaitu nilai-nilai yang terkandung dalam pembukaan UndangUndang Dasar Tahun 1945, nilai instrumental yaitu arahan dan kebijakan lembaga pelaksana yang merupakan hasil penjabaran dari nilainilai dasar dalam rangka penyesuaian untuk melaksanakan nilai-nilai dasar ideologi Pancasila. Nilai Praktis yaitu penjabaran dari nilai-nilai instrumental yang bersifat konkret dalam kehidupan. Nilai ini sangat dinamis pada suatu tempat dan keadaan tertentu. Nilai praktis ini akan terlihat apakah nilai-nilai Pancasila sesuai atau tidak sesuai dengan perkembangan zaman, ilmu pengetahuan, dan dinamika masyarakat seperti toleransi, demokrasi, kerjasama, saling menghargai dan lain-lain.

Dinamika dalam menerapkan nilai Pancasila sering terbentur oleh individuindividu dan kelompok-kelompok yang sering mengadu Pancasila dan agama. Permasalahan yang sering terjadi pergesekan sosial, kerusuhan, kecemburuan sosial serta ketimpangan ekonomi sering disandingkan dengan agama dan dibenturkan dengan Pancasila. Sejatinya hubungan Pancasila dan agama sangat harmonis, yaitu terjadinya hubungan mutualisme yang saling menguntungkan keduanya, Pancasila membutuhkan agama dalam menjalankan kehidupan bernegara agar terciptanya kehidupan negara yang bermartabat, adil dan mengutamakan kepentingan masyarakat dan agama membutuhkan negara dalam merealisasikan nilai-nilai agama agar masyarakat dapat menjalankan kewajibannya untuk mendekatkan diri kepada Tuhan Yang Maha Esa.

Pernyataan yang mengganggu publik pada awal tahun 2020 mengenai "Agama Musuh Pancasila" yang disampaikan ketua Badan Pembinaan Ideologi Pancasila (BPIP) Yudian Wahyudi menjadi pertanyaan semua kalangan, apakah ketua BPIP merupakan seorang yang menganut paham sekuler atau tidak. Badan Pembinaan Ideologi Pancasila (BPIP) merupakan lembaga resmi pemerintahan yang berada langsung di bawah presiden dan bertanggung jawab langsung kepada presiden. BPIP memiliki tugas membantu presiden untuk merumuskan arah kebijakan pembinaan ideologi Pancasila, melaksanakan koordinasi dan pengendalian pembinaan ideologi Pancasila secara menyeluruh dan berkelanjutan.

Pernyataan yang dikeluarkan Yudian Wahyudi selaku ketua BPIP merupakan kekeliruan dalam berpikir bahkan kecacatan dalam berpikir dan berkomentar. Secara substantif agama merupakan hal positif untuk Pancasila. Dalam Pancasila pasal pertama disebutkan Ketuhanan Yang Maha Esa dan diakui dalam Undang-Undang Dasar 1945 pasal 29, dan juga Soekarno pernah menyampaikan Indonesia merupakan negara ber-tuhan dan harus ber-tuhan. Bahkan sejarah lahirnya Pancasila merupakan bentuk 
kelapangan dan ketulusan hati pejuang agama untuk menjadikan Pancasila sebagai dasar negara dengan menghapus 7 kata dalam Piagam Jakarta. Pancasila telah ditetapkan dan disetujui oleh pejuang dan tokoh negara pada saat kemerdekaan dan merupakan hasil panjang dari perumusan dasar negara. Sempat terjadinya perdebatan panjang dan adu argumen yang kuat antara Soekarno dengan Muhammad Natsir mengenai dasar negara serta adanya tekanan dari paham-paham sekuler yang dianut oleh beberapa tokoh. Hingga akhirnya Pancasila lahir dari hasil perdebatan panjang dan adu argumen antara kelompok nasionalis dan kelompok agama mengenai dasar negara. Kelapangan hati dan pikiran dari beberapa tokoh yang ingin menjadikan negara Indonesia sebagai negara Islam menjadi hal yang sangat harus dijunjung tinggi karena tidak ada pergesekan, perpecahan dan konflik yang terjadi setelah dasar negara yaitu Pancasila ditetapkan.

Seharusnya sikap dan tindakan yang dilakukan tokoh-tokoh besar pendiri agama seperti ini sangat perlu dicontoh oleh seluruh aspek, golongan, dan tingkat masyarakat Indonesia, karena Pancasila sebagai ideologi negara lahir dari agama dan unt uk keseluruhan agama dan tidak bisa dijadikan alat untuk mengadu dan diadu dalam segala kondisi dan aspek kehidupan.

\section{PENUTUP}

Hubungan agama dan negara senantiasa menghadirkan sebuah tatanan pengelolaan negara yang berlandaskan Ketuhanan Yang Maha Esa. Agama dan Pancasila tidaklah bermusuhan, bahkan keduanya disatukan atas kesadaran yang menimbulkan keuntungan, agama membutuhkan negara sebagai bentuk realisasi kehidupan dalam pengelolaan negara yang adil, bijaksana dan dapat menyejahterakan masyarakat serta memberikan keleluasaan bagi individu-individu untuk merealisasikan spiritualnya kepada Tuhan Yang Maha Esa. Negara membutuhkan agama dan secara konstitusi mengurusi agama dan kepercayaan sehingga muncul pluralisme dan toleransi dalam menjalankan kehidupan bernegara. Negara secara aktif harus melindungi setiap individu-individu sehingga terciptanya kerukunan umat beragama dan sesuai dengan Bineka Tunggal Ika.

Agama bukanlah musuh Pancasila, dan Pancasila bukanlah musuh agama, seringnya terjadi pergesekan dan kesalahpahaman serta mengadu agama dan negara menjadi permasalahan bangsa Indonesia. Pada saat ini, mendefinisikan bukan negara sekuler dan negara Islam, melainkan negara ber-tuhan dan dijamin oleh konstitusi. Negara ber-tuhan yang berlandaskan Ketuhanan Yang Maha Esa sebagai pedoman dalam kehidupan berbangsa dan bernegara.

\section{Ucapan Terima Kasih}

Terimakasih dihaturkan kepada semua pihak yang telah membantu perwujudan tulisan ini. Secara khusus disampaikan kepada Jusuf Kalla School of Government, Universitas Muhammadiyah Surakarta, dan Redaksi Jurnal AL-Qalam Balai Litbang Agama Makassar yang terlah berkenan melakukan reviewer dan pemuatan tulisan ini. Kepadanya disampaikan Jazakallah Khairan Katsiran. Semoga Allah Swt., memberikan rahmat dan hidayah-Nya kepada kita semua.

\section{DAFTAR PUSTAKA}

Ahda, A. 2017. Tinjauan Kritis Fundamentalisme Dan radikalisme Islam Masa Kini. Kuriositas, 11(1), 1936.

Ahmad, S. 1999. Polemik Negara Islam Soekarno Vs Natsir. Jakarta: UI Press.

Al-Mawardi, A.-M. 1950. Adab Ad-Dunya wa Ad-Din. Kairo: Kairo, Dar Al-Syaibah.

Arianto, B. 2018. Kiprah Natsir Dalam Memperjuangkan Negara Islam Indonesia. Jurnal Kemudi, 2(02), 104126.

Arifin, Z., \& Rizal, S. 2016. Menangkal Radikalisme Di Sekolah. Islamuna: Jurnal Studi Islam, 1(4), 53. 
Asmaroini, A. P. 2017. Menjaga Kelestarian Pancasila dan Penerapannya Bagi Masyarakat di Era Globalisasi. Jurnal Pancasila Dan Kewarganegaraan, 1(2), 50-64.

https://doi.org/10.1016/j.sbspro.2015.0 4.758

Asrori, A. 2017. Radikalisme Di Indonesia: Antara Historisitas Dan Antropisitas. Kalam, $\quad 9(2), \quad 253$. https://doi.org/10.24042/klm.v9i2.331

Asshiddiqie, J. 2006. Hukum Tata Negara dan Pilar-Pilar Demokrasi. Konstitusi Pers, Padmo.

Aziz, A. 2016. Memperkuat Kebijakan Negara dalam Penanggulangan Radikalisme di Lembaga Pendidikan. HIKMAH Journal of Islamic Studies, XII(1), 2956.

Eddy, I. W. 2018. Aktualisasi Nilai Pancasila Dalam Kehidupan Berbangsa dan Bernegara. Ilmu Agama Dan Kebudayaan, 1(18), 1-10. https://doi.org/https://doi.org/10.32795 /ds.v1i18.108

Fauzi, A. 2017. Agama, Pancasila dan Konflik Sosial di Indonesia. E-Journal Lentera Hukum, 4(2), 122. https://doi.org/10.19184/ejlh.v4i2.5295

Hamidi, H., Jazim, J., \& Abadi, A. 2001. Intervensi Negara Terhadap Agama. Yogyakarta: UII Press.

Hasan, H. 2015. Hubungan Islam Dan Negara: Merespons Wacana Politik Islam Kontemporer di Indonesia. Al-Ahkam, 25(1), 19-42. https://doi.org/10.21580/ahkam.2015.1 .25 .192

Hilmy, M. 2015. Radikalisme Agama Dan Politik Demokrasi Di Indonesia PascaOrde Baru. MIQOT: Jurnal Ilmu-Ilmu KeIslaman, 39(2), 407-425. https://doi.org/10.30821/miqot.v39i2.3 3

Ishak, M. 2014. Hubungan Antara Agama Dengan Negara Dalam Pemikiran Islam. Jurnal Tahkim, 10(2), 109-131.

James, L., \& Lutz J, B. 2004. Global Terrorism. London: Routledge London.

Kasmuri, K. 2014. Fenomena Sekularisme. Jurnal Pemikiran Islam Dan Filsafat, 11(3), 89-99.
Laisa, E. 2014. Islam dan Radikalisme. Islamuna: Jurnal Studi Islam, 1(1), 118. https://doi.org/10.19105/Islamuna.v1i1 .554

Mahfud, M. 2017. Politik Hukum di Indonesia. Jakarta: Rajawali Press.

Manggalatung, A. S. 2017. Pancasila Tidak Bertentangan Dengan Agama. Hukum Dan Keadilan, 1(9), 89-90. https://doi.org/10.15408/sd.v2i2.2815. Alfan

Mufid, F. 2016. Radikalisme Islam Dalam Perspektif Epistemologi. Jurnal Addin, 10(1), 61-82. https://doi.org/10.30603/au.v16i2.159

Mulyono, M. 2016. Pancasila Sebagai Orthodoksi Dan Orthopraksis Dalam Kehidupan Berbangsa Dan Bernegara. Humanika, 23(2), 40. https://doi.org/10.14710/humanika.v23 i2. 13644

Muslimin, H. 2016. Tantangan Terhadap Pancasila Sebagai Ideologi dan Dasar Negara Pasca Reformasi. Jurnal Cakrawala Hukum, 7(1), 30-38. https://doi.org/10.26905/idjch.v7i1.179 1

Pramono, A. 2018. Ideologi dan Politik Hukum Pancasila. Gema Keadilan, 5(1), 74-83.

Qodir, Z. 2014. Radikalisme Agama Dalam Kajian Sosiologi. Sosiologi Reflektif (Vol. 9). Yogyakarta: Pustaka Pelajar.

Rijal, S. 2017. Radikalisme Kaum Muda Islam Terdidik Di Makassar. Al-Qalam, 23(2), 335-345. https://doi.org/10.31969/alq.v23i2.434

Ritaudin, M. S. 2014. Radikalisme Negara Dan Kekuasaan Perspektif Politik Global. Kalam, 8(2), 389. https://doi.org/10.24042/klm.v8i2.302

Romli, L. 2006. Islam Yes Partai Islam Yes, Sejarah Perkembangan partai-Partai Islam di Indonesia. Jakarta: Pustaka Pelajar dan LIPI.

Sahidah, A. 2011. Islam dan Demokrasi di Malaysia: Hubungan Agama dan Negara yang Unik. Millah, 10(2), 213226.

https://doi.org/10.20885/millah.vol10.i ss2.art2 
Shaleh, A. I., \& Wisnaeni, F. 2019. Hubungan Agama Dan Negara Menurut Pancasila Dan Undang-Undang Dasar Negara Republik Indonesia Tahun 1945. Jurnal Pembangunan Hukum Indonesia, 1(2), 237-249.

Supriadi, Y. 2017. Hubungan Agama dan Negara dalam perspektif Aksi Bela Islam. Jurnal Aqidah Dan Filsafat Islam, 1(1), 37-48.

Sutrisno. 2016. Peran Ideologi Pancasila Dalam Perkembangan Konstitusi Dan Sistem Hukum Di Indonesia. Jurnal Pancasila Dan Kewarganegaraan, 1(1), 41-49.

Syamsudin, D. 2000. Etika Agama Dalam Membangun Masyarakat Madani. Jakarta: PT Logos Wacana Ilmu.

Teng, H. M. B. A. 2016. Orientalis Dan Orientalisme Dalam Prespektif Sejarah. Ilmu Budaya, 4(2354-724), 48-63.
Thaba, A. A. 1996. Islam dan Negara Dalam Politik Orde Baru. Jakarta: Gema Insani Press.

Widisuseno, I. 2015. Azas Filosofis Pancasila Sebagai Ideologi Dan Dasar Negara. Jurnal Humanika, 20(2), 62-66. https://doi.org/10.14710/humanika.20. 2.62-66

Yunus, A. F. 2017. Radikalisme, Liberalisme dan Terorisme: Pengaruhnya Terhadap Agama Islam. Jurnal Online Studi AlQur An, 13(1), 76-94. https://doi.org/10.21009/jsq.013.1.06

Yunus, N. R. 2016. Aktualisasi Demokrasi Pancasila dalam Kehidupan Berbangsa dan Bernegara. SOSIO DIDAKTIKA: Social Science Education Journal, 2(2), 156-166.

https://doi.org/10.15408/sd.v2i2.2815 